\title{
PENGARUH PERSEPSI PENERIMAAN TEMAN SEBAYA TERHADAP KESEPIAN PADA REMAJA
}

\author{
Ajeng Triani \\ Psikologi, Fakultas Ilmu Pendidikan, Unversitas Negeri Jakarta \\ Rawamangun Jakarta Timur
}

Email : ajengtriani25@gmail.com

\begin{abstract}
Abstrack
This research is aimed to analyze the influence of perception of peer acceptance to loneliness in adolescense. The research was conducted at Jakarta on June 2012.

The population of this research are adolescences at Jakarta between 12 years old until 21 years old. Data was gathered by using scale and analyze by regression test (Anareg) using SPSS 16.0 program. The result revealed that Adjusted R Square perception of peer acceptance on loneliness was 0.051 (5.1\%), which means that peer acceptance influence loneliness as much as $5.1 \%$ and the rest $94.9 \%$ influence by other factors beyond loneliness. The result of this research showed Ho is rejected and Ha is accepted, therefore the research conclusion was that perception of peer acceptance influenced loneliness toward adolescence.
\end{abstract}

Keywords : Perception of Peer Acceptance. Loneliness, Adolescences, Jakarta

\section{PENDAHULUAN}

Kesepian merupakan salah satu masalah psikologis yang tidak dapat dipisahkan dalam kehidupan manusia. Setiap manusia pernah menghadapi situasi yang dapat menyebabkan kesepian. Menurut Burns (1988) berjuta-juta manusia kini adalah manusia yang kesepian, terkucil, terpisah dari hubungan dengan teman, sahabat, atau pasangan. Hubungan yang akrab dengan sesama semakin sulit dicari sehingga kesepian merupakan masalah yang tidak terhindarkan. Apabila manusia mengalami kegagalan dalam menjalin hubungan sosial maka manusia akan mengalami kesepian. Intensitas kesepian berbeda-beda pada tiap individu, ada yang dapat segera melalui perasaan kesepian, namun ada juga individu yang terus menerus merasakan kesepian. 
Kesepian bukan merupakan suatu gejala yang langka dan luar biasa. Kesepian telah menjadi sebuah fenomena yang universal, yang dapat dirasakan oleh setiap individu, hal ini didukung oleh pernyataan Graham (1995) yang mengatakan bahwa kesepian dapat menyerang individu setiap saat, tanpa memilih tempat atau keadaan. Individu dalam sebuah keramaian dapat mengalami kesepian karena merasa terasing, individu tersebut merasa tidak terpenuhi kebutuhan sosialnya meskipun dikelilingi oleh banyak orang. Kesepian berbeda dengan kesendirian, jika seseorang sedang sendirian, belum tentu ia merasa kesepian, hal ini diperjelas oleh Weiss (dalam Pepleu dan Perlman, 1982) yang menga takan bahwa kesepian tidak disebabkan oleh kesendirian, namun disebabkan karena tidak terpenuhinya kebutuhan akan hubungan atau rangkaian hubungan yang pasti, atau karena tidak tersedianya hubungan yang dibutuhkan oleh individu tersebut.

Dalam bahasa asing, kesepian dapat disebut dengan istilah loneliness. Beberapa ahli memberikan pemaparan tentang definisi kesepian diantaranya adalah De Jong Gierveld (1999), Ia mendefinisikan kesepian sebagai kondisi isolasi sosial yang subyektif (subjective social isolation), di mana situasi yang dialami individu tersebut dirasa tidak menyenangkan dan tidak diragukan lagi terjadi kekurangan kualitas hubungan (lack of quality of relationship). Selain itu, jumlah (kuantitas) jalinan hubungan yang ada pada individu juga ditemukan lebih sedikit dari yang diharapkan dan diterima, serta situasi intimacy (keakraban) yang diharapkan juga tidak pernah terealisir (Latifa dalam Jurnal Enlightment, 2008). Berdasarkan pernyataan tersebut, dapat diasumsikan bahwa kesepian terjadi karena kurangnya hubungan dengan orang lain dan individu merasa tidak menemukan hubungan yang istimewa dengan orangorang yang berada di sekitarnya.

Kesepian dapat menimbulkan akibat negatif pada individu. Individu yang merasakan kesepian bisa melakukan hal-hal spontanitas yang kadang diluar nalar. Seorang psikiater dari Swiss, Tournier (dalam Graham, 1995), bahkan menyebut kesepian sebagai penyakit yang paling menghancurkan pada zaman sekarang. Individu yang menderita kesepian akan terhambat kemampuannya untuk berkembang dengan baik dan melakukan kegiatan-kegiatan yang produktif. University of Illionois menjelaskan mengenai hasil penelitian Lambert bahwa ada perilaku-perilaku tertentu yang sering dilakukan individu untuk mengatasi rasa kesepian, beberapa diantaranya adalah: perilaku konsumtif, pesta-pora, tidur, menangis, menyendiri, menonton $\mathrm{TV}$, ikut dalam kelompok tertentu, minum-minuman keras, menggunakan narkoba, atau bahkan sampai mencoba bunuh diri.

Masyarakat seringkali menganggap bahwa kesepian banyak dialami oleh individu pada kelompok usia lanjut, usia dimana seorang individu yang tinggal sendiri karena sudah ditinggal oleh pasangannya, atau usia dimana individu sudah tidak lagi mengurus anaknya. Graham (1995) justru menyebutkan bahwa kesepian yang dialami remaja pada zaman sekarang jumlahnya semakin meningkat dari jumlah tahun-tahun sebelumnya. Badan survey UNICEF bahkan menyebutkan Jepang merupakan Negara dengan tingkat remaja kesepian yang paling tinggi (antaranews.com). Hasil survei nasional di Amerika yang dilakukan oleh majalah Psychology Today (dalam Sears, 1994), memperlihatkan bahwa dari 40.000 individu, yang kadang-kadang bahkan seringkali merasa kesepian adalah individu pada kelompok usia remaja, yaitu sebanyak $79 \%$, dibandingkan dengan kelompok individu yang berusia diatas 55 tahun, yaitu hanya $37 \%$. Berdasarkan fakta tersebut, dapat terlihat gambaran bahwa remajalah yang paling banyak merasakan kesepian saat ini.

Remaja di Indonesia tampaknya juga tidak luput dari permasalahan kesepian tersebut. Banyak fenomena yang terjadi pada remaja akibat perasaan kesepian. Remaja yang sedang berada di masa transisi ini, terkadang tidak mampu bertahan dengan perasaan kesepian. Sebagai contoh sebuah kasus bunuh diri dilakukan oleh remaja berusia 15 tahun berinisial LU. Remaja yang masih bersekolah di sekolah negeri di Jakarta tersebut menurut hasil penyelidikan pihak Polda Metro Jaya, kasus bunuh diri tersebut terjadi karena korban merasa kesepian, tidak mampu bersosialisasi dengan keluarga maupun teman, tidak mampu mengikuti pelajaran dengan baik, dan sering diejek teman karena pernah tidak naik kelas (www.news.indosiar.com).

Selain tindakan yang ekstrim tersebut, remaja di Indonesia yang mengalami kesepian juga seringkali terlibat dalam tindakan-tindakan yang berdampak negatif, seperti: merokok, berkelahi, terlibat por nografi, perilaku seks bebas, serta penyalahgunaan narkotika dan psikotropika. Pikas atau Pusat Informasi Keluarga Berkualitas (www.bkkbn.go.id), memaparkan semakin banyaknya kasus-kasus perilaku remaja yang berdampak negatif, beberapa diantaranya, yaitu: kebiasaan merokok. Hasil survei harian menyatakan, yaitu 38,9\% pelajar Sekolah Menengah Pertama (SMP) mengenal rokok 
sejak usia 12 tahun; juga fenomena tawuran pelajar yang semakin meningkat tiap tahun baik kuantitas maupun kualitasnya; penggunaan narkoba, saat ini sedikitnya terdapat lima juta orang pecandu narkoba, $75 \%$ diantaranya berusia 14 tahun sampai dengan 25 tahun.

Hasil survei Lembaga dan Pembinaan Masalah Narkotika dan Generasi Muda Indonesia diketahui dari 100 kasus tawuran pelajar, sebanyak $67 \%$ adalah pengguna narkoba. National Institute on Drug Abuse (NIDA) merilis hasil survey tahun 2011 tentang perkembangan penggunaan narkoba di kalangan remaja, dan hasilnya: Jumlah remaja yang mengkonsumsi rokok dan alkohol berkurang, tetapi jumlah remaja yang merokok ganja meningkat. Menurut hasil penelitiannya, sekitar $25 \%$ dari remaja $m$ engatakan bahwa mereka mencoba ganja setidaknya sekali setahun, dan sejak tahun 2007 naik sekitar 4\%. Selain itu, 6,6\% dari siswa kelas 12 juga mengaku merokok ganja sehari-hari. Peningkatan penggunaan ganja tertinggi terjadi pada tahun 1981. Pada tahun yang sama, penggunaan rokok dan alkohol juga mencapai posisi terendah dalam sejarah. Sebanyak $11,7 \%$ dari remaja AS mengisap rokok dalam 30 hari terakhir, dibandingkan dengan $12,8 \%$ pada 2010 . Salah satu contoh nyata di Indonesia, yaitu kasus di Medan 2011 lalu, dua orang remaja ARM (17thn) dan SA (14thn) tertangkap basah sedang menggunakan narkotika jenis shabu (Tribunnews.com).

Semakin banyaknya remaja yang mulai terjerumus dalam hal-hal negatif dapat diasumsikan, bahwa remaja tersebut merasakan perasaan kesepian, perasaan yang menyakitkan yang harus dihilangkan sesegera mungkin. Dengan melakukan hal-hal negatif tersebut, maka para remaja mampu memperoleh hubungan sosial baru sebagai penghilang perasaan kesepian. Hal ini diperkuat oleh pernyataan dari Arief (www.narkoba mania.com,) yang mengungkapkan bahwa salah satu penyebab terjadinya kasus-kasus pemakaian obat-obat terlarang pada remaja adalah faktor kesepian. Turner dan Feldman dalam uraian Luthfie (www.bkkbn.go.id) juga mengungkapkan bahwa salah satu tujuan remaja melakukan tindakantindakan tersebut adalah untuk mengatasi rasa kesepian yang dialami. Remaja yang terlibat pada perilaku-perilaku tersebut tidak mampu mengatasi rasa kesepian yang dialami secara tepat, sehingga remaja mencari penyelesaian dengan tindakan salah yang justru dapat berdampak negatif baik pada dirinya sendiri maupun pada orang lain.
Remaja seringkali mendiskripsikan kesepian yang dialami sebagai kekosongan, kebosanan, keterasingan, ketidakmampuan beradaptasi dengan lingkungan sosialnya. Menurut Rice (2008), remaja lebih sering merasa kesepian ketika merasa ditolak, terasing dan tidak mampu memiliki peran dalam lingkungannya. Kesepian yang dirasakan adalah karena belum terbentuknya keintiman baru yang berakibat remaja tidak mempunyai hubungan interpersonal yang intim. Berdasarkan hasil penelitian Pretty dkk (2005) terhadap 234 remaja berusia 13-18 tahun di Australia ditemukan bahwa sense of community and social support mempengaruhi tingkat kesepian pada remaja. Keinginan remaja untuk menjadi bagian dalam sebuah komunitas sosial dan mendapatkan dukungan dari lingkungan sosialnya apabila tidak terpenuhi akan mempengaruhi tingginya tingkat kesepian pada remaja. Selain itu, masa remaja adalah masa yang memerlukan banyak penyesuaian dalam hidupnya, seperti contoh seorang remaja yang sedang berada di bangku SMP, dan akan memasuki bangku SMA, di masa itu seorang remaja dituntut untuk bisa beradaptasi dan dengan segera melakukan penyesuaian dengan lingkungan barunya. Apabila remaja tersebut tidak dapat menyesuaikan diri dengan baik dengan lingkungan sosialnya, maka bukan hal yang mustahil jika remaja tersebut merasakan kesepian.

Masa remaja merupakan salah satu masa yang penting dalam periode perkembangan hidup individu, masa tersebut sering disebut sebagai masa transisi. Pada masa ini, remaja mengalami perkembangan dalam berbaga aspek, yaitu fisik, kognitif emosi, dan sosial. Individu pada masa remaja mulai meninggalkan kebiasaan masa kanak-kanak dan menyesuaikan diri dengan kebiasaan-kebiasaan orang dewasa. Remaja dihadapkan pada tugas-tugas perkembangan yang baru yaitu mencapai hubungan baru yang lebih matang dengan teman sebaya, mencapai peran sosial pria dan wanita, beradaptasi dengan perubahan fisik, mempersiapkan karier ekonomi dan pernikahan (Havighurst dalam Hurlock, 1999). Dalam perkembangan sosial, remaja mengalami perubahan hubungan, remaja mulai memisahkan diri dari orangtua menuju pada keintiman dengan teman-teman sebaya. Condry, Simon, \& Bronfenbrenner (dalam Santrock, 2003) menyatakan bahwa remaja muda laki-laki dan perempuan menghabiskan waktu dua kali lebih banyak dengan teman sebaya daripada waktu dengan orang tuanya. Disinilah mereka saling mengisi dan mempengaruhi satu sama lain dan kadang-kadang membentuk kelompok-kelompok dengan remaja yang memiliki usia sebaya. Menurut Monks dkk (1999) 
perubahan hubungan tersebut memerlukan kesinambungan, perubahan memisahkan diri dari orangtua tanpa disertai perubahan hubungan remaja menuju teman sebaya akan mengakibatkan remaja mengalami kesepian

Teman sebaya merupakan sumber status, persahabatan dan rasa saling memiliki yang penting di sekolah. Teman sebaya dapat mengarahkan remaja ke arah yang positif atau bahkan ke arah yang negatif. Pengaruh teman sebaya yang saat ini dapat terlihat dalam lingkungan sekolah adalah gaya berpakaian, dan gaya rambut yang cenderung sama (pada perempuan), Hal ini juga dikemukakan oleh Santrock (2003), yang mengatakan bahwa kelompok teman sebaya juga merupakan komunitas belajar peranperan sosial dan standar yang berkaitan dengan kerja dan prestasi. Seorang remaja akan lebih banyak menghabiskan waktu bersama teman-temannya dibandingkan orangtuanya, hal ini tentu dirasakan oleh setiap individu, dimana keberadaan teman menjadi sangat penting dalam fase remaja. Hal ini didukung pula oleh Sullivan yang menyatakan bahwa seorang remaja menghabiskan 103 menit per hari untuk melakukan interaksi yang berarti dan 28 menit untuk berkomunikasi dengan orangtuanya.

Menurut Santrock (2003) dengan adanya interaksi dengan teman sebaya, remaja dapat belajar mengenai hubungan timbal balik, prinsip kejujuran dan keadilan, serta dapat meneliti minat teman sebaya dalam upaya memudahkan remaja dalam melakukan penyesuaian diri kepada aktivitas teman sebayanya yang sedang berlangsung. Selain itu, dengan adanya interaksi yang akrab dengan teman sebayanya, remaja meningkatkan harga diri dan kemampuan sosial remaja (Desmita, 2005).

\section{METODE PENELITIAN}

Metode yang digunakan dalam penelitian ini menggunakan metode penelitian kuantitatif. Metode penelitian kuantitatif adalah metode penelitian yang tidak mementingkan kedalaman data, pemecahan masalahnya didominasi oleh peran statistik (Sukardi, 2011)

Desain penelitian ini adalahh expost facto, Kerlinger (dalam Nazir, 1999) mengatakan bahwa penelitian expost facto adalah penyelidikan secara empiris yang sistematik dimana peneliti tidak mempunyai kontrol langsung terhadap variabelvariabel bebas (independent variables) karena
Teman sebaya memiliki peranan yang begitu penting sehingga para remaja berusaha melakukan beragam cara agar bisa diterima oleh teman sebayanya. Adanya penerimaan dari teman sebayanya dapat dilihat dari persepsi mereka atas reaksi dari teman sebayanya. Apabila mereka memandang bahwa teman sebayanya dapat menerima mereka maka mereka akan tahu bagaimana mereka mesti berperilaku dalam kelompok. Sebaliknya, bila mereka memandang bahwa mereka tidak diterima oleh kelompoknya maka berbagai akibat negatif akan timbul. Mereka akan merasa kesepian, tidak aman, memiliki konsep diri yang negatif, kurang memiliki pengalaman belajar, sedih, kurang memiliki keterampilan sosial, dan melakukan penyesuaian sosial secara berlebihan.

Hal ini diperkuat oleh Santrock (2003), yang menyatakan bahwa pengabaian dan penolakan dari teman sebaya juga dapat mengakibatkan para remaja merasa kesepian dan timbul rasa permusuhan yang selanjutnya berhubungan dengan kesehatan mental individu dan masalah kriminal. Selain itu, penolakan dari teman sebaya dalam pertemanan dapat memunculkan perilaku-perilaku negatif. MillerJohnson, dkk (1999) dengan penelitian longitudinalnya menemukan bahwa adanya penolakan dari teman sebaya dapat memunculkan perilaku agresif dan beberapa perilaku menyimpang pada masa remaja.

Melihat adanya keterkaitan tersebut, peneliti tertarik untuk melakukan penelitian ini dengan menguji lebih lanjut mengenai pengaruh antara persepsi penerimaan teman sebaya terhadap kesepian pada remaja.

manifestasi fenomena telah terjadi atau karena fenomena sukar dimanipulasikan.

Pada penelitian ini, subjek penelitian tidak diberikan perlakuan sehingga data yang di ambil adalah apa yang telah dialami subjek. Untuk mendapatkan data yang diinginkan, maka pada penelitian ini menggunakan alat ukur berbentuk kuesioner dengan skala Likert. Dalam penelitian ini, variabel bebasnya yaitu persepsi penerimaan teman sebaya (X), sedangkan variabel terikatnya adalah kesepian (Y). 


\section{HASIL DAN DISKUSI}

Tabel 1.

Jumlah Responden Berdasarkan

Wilayah Tempat Tinggal

\begin{tabular}{ccc}
\hline No & Asal Kotamadya & Jumlah \\
\hline $\mathbf{1}$ & Jakarta Pusat & $\mathbf{3 0}$ \\
$\mathbf{2}$ & Jakarta Barat & 30 \\
$\mathbf{3}$ & Jakarta Timur & 30 \\
& Jumlah & 90 orang \\
\hline
\end{tabular}

Tabel 2.

Jumlah Responden Berdasarkan

Jenis Kelamin

\begin{tabular}{cccc}
\hline No & $\begin{array}{c}\text { Jenis } \\
\text { Kelamin }\end{array}$ & Jumlah & $\begin{array}{c}\text { Persentase } \\
(\mathbf{\%})\end{array}$ \\
\hline $\mathbf{1}$ & Laki-laki & 31 & 34,44 \\
$\mathbf{2}$ & Perempuan & 59 & 65,56 \\
& Jumlah & 90 & 100 \\
\hline
\end{tabular}

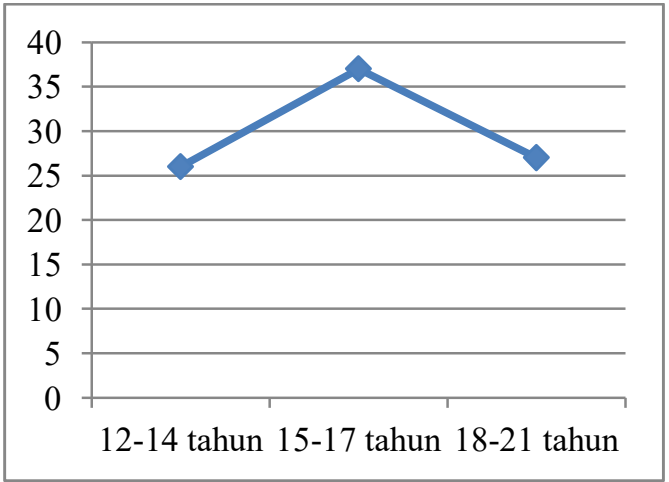

Gambar 1. Jumlah responden berdasarkan usia

Berdasarkan kategorisasi data, dapat terlihat bahwa remaja yang berada dalam kategori tinggi dalam variabel kesepian berjumlah 25 orang, yang berada dalam kategori rendah berjumlah 23 orang, sedangkan sisanya tidak terkategorisasi. Maka dapat disimpulkan bahwa sebesar $27.78 \%$ remaja dari seluruh responden mengalami tingkat kesepian yang tinggi.

Selanjutnya, dalam variabel persepsi penerimaan teman sebaya, terdapat 23 orang berada dalam kategori rendah, 29 orang tidak terkategori dan, 38 orang berada dalam kategori tinggi. Maka sebesar $42.22 \%$ remaja dari jumlah responden berada dalam kategori tinggi.

Dari hasil penelitian dengan analisis regresi sederhana, didapat persamaan regresi $\mathbf{Y}=\mathbf{5 5 . 2 6 5}$ 0.216X. Persamaan tersebut bermakna bahwa variabel kesepian (Y) rata-rata akan berubah sebesar $-0,216$ untuk setiap unit perubahan yang terjadi pada variabel persepsi penerimaan teman sebaya (X). Berdasarkan penghitungan, nilai $\mathrm{F}=5.786$ yang memiliki signifikansi 0,018 maka didapatkan bahwa terdapat pengaruh yang signifikan antara persepsi penerimaan teman sebaya terhadap kesepian pada remaja.

Berdasarkan perolehan tersebut dapat disimpulkan bahwa persepsi penerimaan teman sebaya memiliki pengaruh terhadap kesepian pada remaja di Jakarta. Besarnya sumbangan pengaruh persepsi penerimaan teman sebaya terhadap kesepian diketahui dengan melihat perolehan nilai Adjusted $R$ Square. Nilai Adjusted $R$ Square yang diperoleh pada penelitian ini sebesar 0.051 atau sebersar $5.1 \%$. Hal ini menunjukkan bahwa sisa nya sebesar $94.9 \%$ dipengaruhi oleh faktor lain selain dari penerimaan teman sebaya. Secara statistik nilai ini memberikan penjelasan bahwa kesepian dipengaruhi oleh persepsi penerimaan teman sebaya. 
Persepsi penerimaan teman sebaya merupakan salah satu hal yang memperngaruhi kesepian pada remaja. Selain hal tersebut terdapat pula hal lain yang mempengaruhi perasaan kesepian pada remaja, salah satunya adalah hubungan dengan keluarga, keluarga adalah salah satu kebutuhan pokok bagi perkembangan individu dalam rangka pembentukan karakter yang baik. Dalam prakteknya, beberapa orangtua mengetahui hal ini namun mengabaikannya dengan alasan mengejar karier atau materi demi kebahagiaan. Demikian pula dengan keefektifan komunikasi dengan orangtua yang merupakan hal penting pula dalam perkembangan seorang remaja. Hal ini diteliti oleh Marika (2007), hasil dari penelitian ini menunjukan bahwa ada pengaruh yang signifikan antara keefektifan komunikasi dengan orangtua terhadap perasaan kesepian yang dialami oleh remaja.

Perasaan kesepian yang dialami remaja ini bukan semata-mata disebabkan oleh remaja itu sendiri, melainkan dikarenakan oleh kualitas hubungan dengan orang-orang disekitarnya, Seperti yang diketahui, masa remaja juga merupakan masa dimana seseorang remaja memulai hubungan dengan teman lawan jenisnya, jika remaja tersebut dapat menjalin kualitas hubungan yang baik dengan lawan jenisnya, maka perasaan kesepian yang dialami oleh remaja tersebut tidak akan tinggi, namun jika kualitas hubungan dengan lawan jenisnya kurang baik, maka remaja tersebut akan lebih mudah untuk mengalami kesepian.

Kesepian yang dialami remaja banyak dikarenakan karena hubungan dengan teman-teman sebayanya yang kurang baik. salah satunya dengan penerimaan dari teman-teman sebayanya. Semakin diterima oleh teman sebayanya, makan akan semakin berkurang perasaan kesepian yang dirasakan. Seorang remaja yang dapat diterima dengan baik oleh teman sebayanya akan merasakan perasaan nyaman, serta menyenangkan jika berada di lingkungan teman sebayanya, hal ini merupakan suatu hal yang penting karena menjalin hubungan yang baik dengan teman sebayanya juga merupakan salah satu tugas perkembangan yang seharusnya dijalani oleh remaja.

\section{KESIMPULAN DAN SARAN}

Berdasarkan hasil pengolahan data statistik, dapat diambil kesimpulan bahwa Ho ditolak, sehingga Ha diterima. Kesimpulannya yaitu terdapat pengaruh yang signifikan persepsi penerimaan teman sebaya terhadap kesepian pada remaja.

Saran :

1. Kepada remaja, diharapkan mampu menyesuaikan diri serta membangun interaksi yang baik dalam lingkungan sosialnya, terutama kelompok teman sebaya agar tercipta hubungan yang sehat agak terhindar dari perasaan kesepian.

2. Kepada orangtua, diharapkan mampu menjaga efektitias komunikasi dengan anaknya, karena keluarga tetap memegang peranan utama dalam proses perkembangan remaja, supaya terhindar dari perasaan kesepian.

3. Bagi peneliti selanjutnya, diharapkan mampu mengembangkan penelitian mengenai kesepian di kalangan remaja dengan variabel selain penerimaan teman sebaya, supaya dapat menambah wawasan mengenai psikologi perkembangan dan sosial pada remaja.

\section{DAFTAR PUSTAKA}

Azwar, S. 2001. Reliabilitas dan Validitas. Yogyakarta: Pustaka Pelajar

Burns, D.D., 1988. Terapi Kognitif. Pendekatan Baru Bagi Penanganan depresi. Penerbit Erlangga. Jakarta

Burns, R. B. 1993. Konsep Diri Teori Pengukuran, Perkembangan, dan Perilaku (Terjemahan Eddy). Jakarta: Arcan.

Chaplin, J.P.2004. Kamus Umum Psikologi (Penerjemah Kartino Kertono). Jakarta : PT. Raja Grafindo Persada

De Jong Gierveld, J \& Till Burg, T.V. (1999). Manual of The Loneliness Scale. Vrije Universiteit Amsterdam

Desmita.2005. Psikologi Perkembangan. Bandung: PT Remaja Rosdakarya.

Graham, B. 1995. Kesepian: Bagaimana cara menyembuhkannya? Sukses dan Prestasi: Rahasia Pembaharuan Diri. 04, 11-17. 
Hurlock, Elizabeth B. 1968. Developmental Psychology Edisi ketiga terjemahan. New York: Mc Graw-Hill Book Company.

Hurlock, Elizabeth B. 1980. Psikologi Perkembangan. Edisi kelima. Jakarta: Erlangga.

Kuncono, 2004. Aplikasi Komputer Psikologi. Jakarta: Fakultas Psikologi Universitas Persada Indonesia.

Monks, F.J., dkk. 1999. Psikologi Perkembangan, Pengantar dalam berbagai bagiannya. Yoygakarta: Gadjah Mada University Press

Nazir, Moh. 1999. Metodologi Penelitian. Jakarta: Ghalia Indonesia

Papalia Diane. E, Sally Wendkos Olds, Ruth Duskin Feldman. 2001. Human Development eight edition. New York: Mc Graw Hill

Papalia Diane. E. 1995.Human Development. NewYork, Mc Graw Hill

Pepleu, L.A., dan Perlman, D. 1982. Loneliness : A Sourcebook of Current Theory, Research and Therapy. New York: John Wiley dan Sons

Priyatno, Duwi. 2011. SPSS Analisis Statistik Data. Yogyakarta :MediaKom

Rangkuti, Anna Armeini. 2010. Analisis Data Penelitian Kuantitatif dengan SPSS. Universitas Negeri Jakarta

Rangkuti, Anna Armeini. 2012. Statistika Inferensial untuk Penelitian Psikologi dan Pendidikan. Universitas Negeri Jakarta

Rice, F.Philip. 2005. The Adolescence, Development, Relationship and Culture. Boston: Pearson

Riduwan dan Sunarto. 2009. Pengantar Statistika untuk Penelitian. Alfabeta: Bandung.
Russell, D., (1996). UCLA Loneliness Scale (Version3): Reliability, Validity, and Factor Structure. Journal of Personality Assessment. Volume: 66. Issue: 1. Publication Year: 1996. Page Number: 40

Santrock, John W. 2003. Perkembangan Remaja edisi terjemahan. Jakarta: Erlangga.

Santrock, John W. 2008. Adolescence. New York : Mc Graw-Hill International Edition.

Shaffer D.R (2001). Developmental psychology. USA: Wadsworth.

Sharaswaty, NT. 2009. Hubungan Kesepian dan Agresi pada Remaja yang Berpacaran. Universitas Indonesia

Sukardi. 2011. Metodologi Penelitian Pendidikan Kompetensi dan Praktiknya. Jakarta: Bumi Aksara

Walgito, Bimo.2002.Pengantar Psikologi Urnum. Yogyakarta : Andi

http://www.tribunnews.com/2011/03/18/dua-gadisdi-bawah-umur-tertangkap-nyabu

http://www.antaranews.com/view/?i=1171934446\& $\mathrm{c}=\mathrm{INT} \& \mathrm{~s}=$

http://www.legalisasiganja.com/mengapa-remajalebih-menyukai-ganja-daripada-alkohol/ NIDA

http://www.scribd.com/doc/67029284/HubunganAntara-Konsep-Diri-Dengan

http://www.4skripsi.com/metodologipenelitian/teknik-pengambilan-sampelpenelitian.html\#ixzz1pjfObXj7 